Journal of Clinical Pathology, 1977, 30, 1091-1102

\title{
History of cytodiagnosis
}

\author{
ARTHUR I. SPRIGGS \\ From the Laboratory of Clinical Cytology, Churchill Hospital, Oxford, UK
}

The place, Oxford; the time, around 1845-50. Henry Acland lectured on medicine in a room furnished with "little railroads on which ran microscopes charged with illustrations of the lecture, alternately with trays of coffee'. 'Dr Ogle, applying his eye to the microscope, screwed a quarter-inch right through the object; and Dr Kidd, after examining some delicate morphological preparation, while his young colleague explained its meaning, made answer first, that he did not believe in it, and secondly, that if it were true he did not think God meant us to know it' (Tuckwell, 1907). However apocryphal the story, the setting is authentic. Microscopy in the service of medicine had been long delayed, but within the following 20 years most of the diseases then known had been classified in terms of their histological features.

The father of medical microscopy was the physiologist Johannes Müller. Under his influence Virchow became its greatest exponent. In the first volume of Virchows Archiv (1847), which also contains one of the earliest descriptions of chronic granulocytic leukaemia, he published an extremely long article on the nature of cancer illustrated with two plates full of drawings of tumour tissue and cancer cells. In those days microscopists studying soft tissues had to tease out or spread the material in order to show the component cells. By the seventies medical students knew that the 'tissues' are not primarily tissues at all, in the original sense of fabrics made of woven fibres, but rather colonies of cells which may live in a fibrous framework; Virchow's contention was also accepted, that cells originate only from pre-existing cells.

Malignant cells from solid tumours were described and illustrated by a number of other mid-19thcentury authors; Müller himself published some, but he was more concerned to demonstrate that tumours contain cells at all than to show any difference between benign and malignant ones (Müller, 1840). Illustrations can be found in the works of Donné (1844), Lebert (1851), Donaldson (1853), and Beale

Received for publication 25 July 1977
(1854). Figure 1 shows a small part of one of the plates in Lebert's (1857-61) magnificent Atlas, representing the best quality of drawings made from unstained microscopic preparations. Most of the illustrations of that period, purporting to show that cancer cells are different from normal ones, could never really have been of much practical help, but this can be said equally of some of the half-tone photographs of cells which get printed in medical books and journals today.

The idea of tumour puncture was referred to by Lebert (1851) but it did not develop as a diagnostic method at that time. He also performed measurements on the nuclei and nucleoli and noted the increased nucleo-cytoplasmic ratio in many cancer cells. Measurements of this type were not repeated for many years and are only now having a renewed importance in connection with attempts at automation of cytodiagnosis.

A major technical advance was the use of stains to display the details of nucleus and cytoplasm (see Castiglioni, 1947; Bamforth and Osborn, 1958). Paul Ehrlich used stained air-dried films to identify the cells not only of blood but also of serous effusions. He described (Ehrlich, 1882) the features of adenocarcinoma cells in three pleural effusions, two due to carcinoma of the ovary and one to carcinoma of the breast, but unfortunately provided no illustrations and did not develop this theme any further.

In spite of the introduction of staining methods, unstained wet preparations have continued to be used right up to our own time, especially for the routine examination of urine. Also certain advances in the identification of malignant cells were made without stains, even in the 20th century-for instance, Marini's (1909) remarkable study of gastric washings. Some workers preferred supravital methods or stains applied to cells in suspension, as in Quensel's (1928a, b) beautiful studies of the cytology of serous fluids.

Microscopists have used thin slices ever since the time of Leeuwenhoek, but the staining of sections constituted the breakthrough for histology as we 


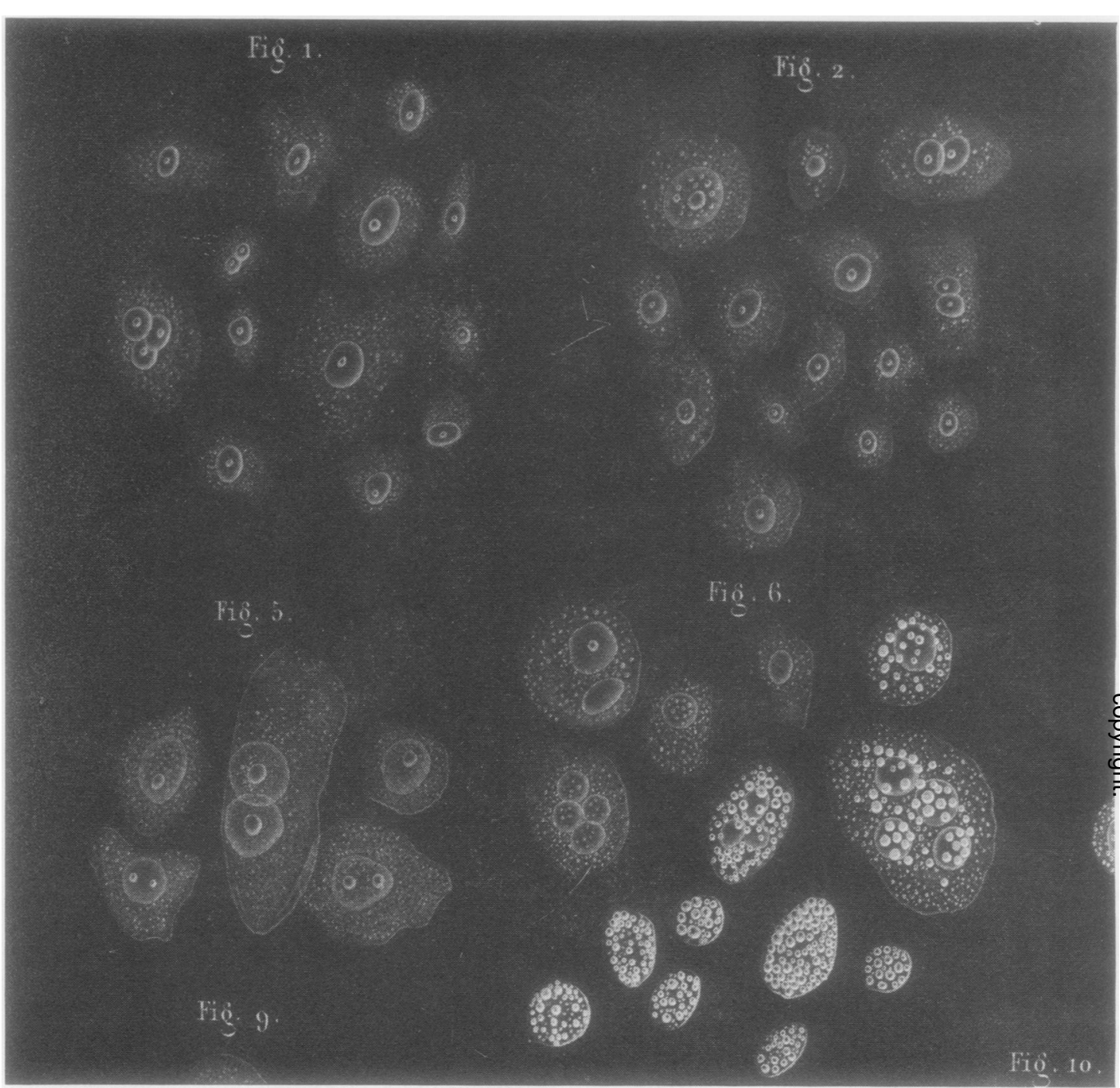

Fig. 1 Part of Plate XLI of Lebert's (1857-61) Traité d'Anatomie Pathologique showing cancer cells. His Figs. 1 2, and 5 are cells from uterine carcinoma, and Fig. 6 from carcinoma of the stomach. (Photograph by courtesy of the Bodleian Library.)

know it. It is obvious that a pathologist who never used stained sections but relied on smears and imprints would lose the greater part of his essential visual data. But the converse is also true, that by examining sections only, and not seeing the cells displayed to full advantage, histopathologists lose information which would improve diagnostic precision. The simultaneous use of both types of preparation unfortunately became difficult as soon as the histopathologist began to receive material fixed at the time of collection, since what was necessary for good sections was ruinous for cell prepara- tions. From the introduction of paraffin embedding in about 1880 , cytological methods were gradually abandoned for all solid tissues and finally retained only in the domains of haematology, parasitology, and bacteriology. Even so, textbooks of pathology continued almost up to the end of the 19th century to print line drawings showing cells teased or scraped from solid tissues (including tumours); they were copied, for instance, from Billroth's 'Lectures on Surgical Pathology and Therapeutics', which went into many editions from 1863 onwards.

Until the 1930s, the occasional medical micros- 
copist reported his experiences with the examination of serous fluid, sputum, urine, and so on, but these studies did not serve as bridgeheads from which advances were subsequently made; it seems that each discovery was forgotten and never added to the corpus of knowledge handed down to successive generations of pathologists. Probably, as a result of many (unpublished) false positive diagnoses made by inexperienced pathologists using inadequate cytological methods, the tradition handed down was one of scepticism. In the words of Roodhouse Gloyne (1919), speaking of malignant cells, it is practically impossible to identify these cells, in film preparations'.

\section{Vaginal and cervical smears}

The cytology of vaginal secretion was described by Donné (1844) and Pouchet (1847), but not in connection with the diagnosis of cancer. Pouchet's monograph is remarkable in that it describes the findings at different stages of the human menstrual cycle. ${ }^{1}$ In clinically suspected cervical carcinoma, cytological examination was recommended by Richardson (1871) in the United States, who wrote: 'In suspected cancer of the womb . . . a small portion of the secretion from the os uteri, or from the ulcerated surface of the growth itself, should such exist, must therefore be removed by means of a probe or pair of forceps introduced through a speculum, and on examination with a power of 200 diameters will probably disclose at least a few cells on each slide, which will indicate with more or less certainty the character of the morbid formation.' Friedlaender (1886) also used this method but warned against diagnosing carcinoma from the cytology alone; he recommended also a histological examination of a little piece of excised tissue, a procedure which about 10 years later became known as 'biopsy'.

The vaginal smear was first systematically used by Papanicolaou and has rightly become known by his name. Recently his biography has been written by Carmichael (1973). George N. Papanicolaou qualified in medicine in Athens in 1904. He then specialised in zoology, especially the experimental study of reproduction. In 1913 he emigrated to New York, and from then onwards for many years he studied the oestrous cycle in animals and the menstrual cycle in the human female. He introduced the vaginal smear for this purpose in 1917 (Stockard and Papanicolaou, 1917) and, after many other publications, there appeared in 1933 'The sexual

1 For reproductions of his drawings, see Bamforth and Osborn (1958). cycle in the human female as revealed by vaginal smear'.

In the course of studies on patients in the Women's Hospital, New York, Papanicolaou saw malignant cells in vaginal smears, and in 1928 he gave his first paper on this subject at a conference, entitling it 'New cancer diagnosis'. Figure 2 shows one of his photographs with the accompanying text. He thought that the mononuclears reacted to the cancerous toxins in such a way as to make them cytologically recognisable so that the diagnosis could be made without finding actual cancer cells. There were no case-histories or statistics nor any cytohistological correlation. Moreover, the paper as published was badly marred by errors of transcription which were not corrected in proof; this, coupled with the prevailing climate of opinion, prevented any widespread interest from being aroused at that time.

Simultaneously and independently, cancer cells were recognised in cervical smears by Aurel Babeș of Bucharest. Babeş was a pathologist, who collaborated with his uncle Victor Babeş in writing a four-volume textbook of pathological anatomy, and who also published research on the pathogenesis of pellagra and of typhus and other infectious diseases, and later on endocrinology and cancer research, altogether publishing 283 scientific papers. In 1927, with C. Daniel, he presented to the Bucharest Gynaecological Society (Fig. 3) a new method for the diagnosis of carcinoma of the cervix, using a platinum loop to transfer material from the affected area to the slides. They were then air-dried and stained with Giemsa.

The results were published, with clear and informative drawings, in the Presse Médicale of 11 April 1928, and cervical smears continued to be used in the gynaecological clinics of Professor Daniel from that time onwards. (A translation of the 1928 article has been published with the illustrations (Douglass, 1967).)

In an article on carcinoma in situ of the cervix uteri in 1931, Babeş said that the smear method had been used on a large scale by Kermauner and Schiller; however, it does not appear to have taken root, and Babeş's contribution was practically forgotten. Before he died in 1962 he was given credit in Europe (Zinser, 1957; Boddington et al., 1960), and J. E. Ayre referred to him in the atlas Cancer Cytology of the Uterus (1952), though he made him come from Budapest instead of Bucharest; but his work was probably unknown to Papanicolaou, who died in the same year, and Babes modestly refrained from ever raising the question of priority.

Returning to New York between the wars, we find Papanicolaou patiently studying endocrinological problems until the appointment of Joseph Hinsey to 


\section{TIIE THIND RACE BETTEKMENT CONFEKENCF.}

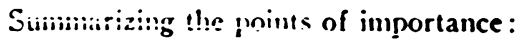

First: We have a new diagnostic method for certain malignant tumors, especially of the female genital tract.

Sccond: The methods and the technique used are very simple ones. and can easily be applied in every case.

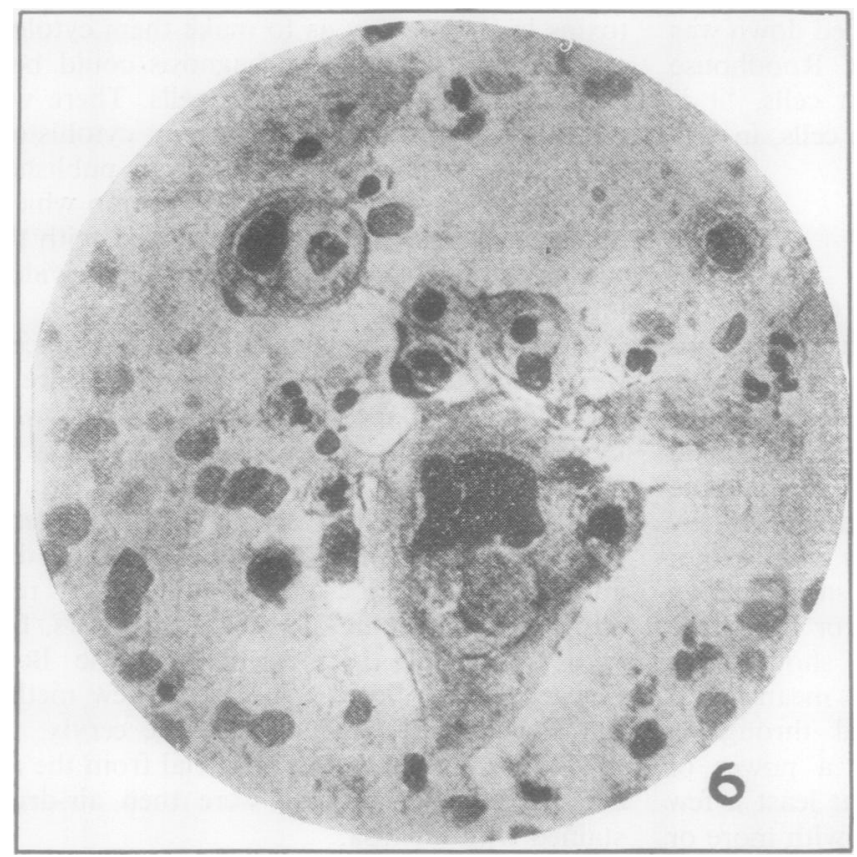

Fis. "A. Anether cancerous cell with large. hyperchromatic and fraknenteri nuc and with a larke vacuole in its cytoplasm. Many erythrocytes are present in the stm. few lew.......... and several monocytes, which are more affected than

Third: The recognition of malignancy is based no: only on the prescnce of malignant cells but also on the reaction of ihe organism itself.

Fourth: We have a better understanding of the situation in a cancer case, and we may have some help in analyzing the cancer problem in the future. In fact, I think this work will be carried a little further, and that analogous methods may be applied in the recognition of cancers in other organs. I think that some such method can be and will be developed in the future.

the Department of Anatomy at Cornell. With Hinsey's support, Papanicolaou returned to the question of cancer diagnosis and in 1941, with Herbert Traut, he published 'The diagnostic value of vaginal smears in carcinoma of the uterus'. This was followed in 1943 by the monograph, Diagnosis of Uterine Cancer by the Vaginal Smear, beautifully illustrated with coloured drawings by Murayama.
This time medical opinion was less antagonistic. In particular, many gynaecologists became enthusiastic about the possibility, mentioned by Papanicolaou, of identifying cancer of the cervix at an early and curable stage.

Very soon, with an increased awareness of the possibility that very early or even precancerous stages of the disease are histologically recognisable
Fig. 2 The final page of Papanicolaou's paper of 1928. 
Socielatea de Gynecologie

Prese finte Prol. C. DANiec

Sedinja din 23 lanua le 1927

1

Posibilitatea diagnosticului cancerului uterin cu sjutorul frotiului

de Prof. C. Daniel si A. Babes

Având in vedere dificultăfile In unele cazurl de a practica - biopsle in cazuri suspecte de cancer uterin este de dorit a se putea in aceste cazıri sa se stabilească diagnosticul anatomo patologic prin alte metode.

In acest scop s'a incercat in un număr de 10 cazurl in parte cu lezluni cancer, in parte fáră cancer, a se stabili diagnosticul pe baza unor frotiuri de la nivelul leziunilor. Acest nou procedeu cu rezultatele care le-a dat până in prezent, promite cu adevắr a deveni un procedeu de utilitate practică.

Acest procedeu e $b$ zat pe prezenta in frotiurile fácute in cazlirile de cancer a unel atipli celulare, precum şi a prezentei de placarde epiteliale mai mari, pe lángă atipille celulare. Se poate ionstata o mal mare variabilitate in caracterul celulelor epiteliale.

Aceste caractere lipsind in afară de cazurile fáră leziuni canceroase, credem că vor putea serỵl la diferentiarea acestor 2 í luri de leziuni.
Fig. 3 The abstract of Daniel and Babes's paper of 1927 (Possibility of diagnosing uterine cancer by means of smears). The material was fully presented and illustrated in an article by Babes the following year in the Presse Médicale. The second paragraph may be translated:

'With this object, it was attempted to establish the diagnosis in 10 cases, some with and some without cancer, by means of smears from the lesions. This new procedure, from the results obtained so far, indeed promises to become a procedure of practical usefulness.' and can be found by the 'Pap smear', clinicians (and interested laymen too) began to demand that these tests should become available. This meant training programmes, and the unassuming Dr Papanicolaou found himself in 1947 running a course in cytological diagnosis with an initial intake of 70 . He also continued investigating the identification of cancer cells in many other sites, particularly in urine, sputum, gastric washings, and breast secretions. Every application was quickly taken up and confirmed by other cytodiagnosticians, who became known as 'exfoliative cytologists'. Although Papanicolaou's counterstains were devised to show the stages of maturation of squamous epithelial cells, the same method was applied to every other material. Where a body of expertise existed already, using some other technique (for instance, the haematological practice of air-drying before fixation and staining with Romanowsky dyes), an uncomfortable conflict developed and continues to this day.

By 1954 Papanicolaou had produced his comprehensive Atlas of Exfoliative Cytology. His activity continued undiminished until his death in 1962 at the age of 78 years.
During the fifties there was a deluge of literature on this subject. Almost everyone who used Papanicolaou's methods apparently felt the need to publish. Suddenly there appeared a new body of literature with a new jargon and concepts which at first were unsupported by properly controlled observations. To many pathologists these concepts seemed unacceptable at the time, though they have become more respectable now. In particular, many pathologists distrusted the evangelism with which converts to the new discipline sought to press on with the conquest of uterine cancer. These facts of history serve to explain why clinical cytology was only slowly accepted as part of the normal training of a pathologist, though Shields Warren wrote in the preface to Gates and Warren's illustrated Handbook (1947): 'It is on the practising pathologist that the onus of this task will fall.'

The emergence of a body of trained exfoliative cytologists made possible the rapid development of population screening, first by the vaginal smear and soon after by the cervical scraping introduced by Ayre $(1947,1952)$. In the event this timetable proved to be a misfortune, because population screening 
became an accepted practice before the general introduction of randomised controlled trials. A proper trial could have given a clear indication of the extent of benefit to be expected from defined screening strategies, and services could have been rationally planned instead of becoming a football between Public Health authorities, epidemiologists, lay pressure groups, politicians, and clinical cytologists. There are very strong reasons for supposing that cervical cancer can, in principle, be prevented by this means (Spriggs, 1972), but the application of it to most of the women at highest risk is still only a hope for the future.

\section{Cytodiagnosis from sputum}

During the second half of the 19th century there were many medical microscopists who studied the cells of sputum, but their concern was generally with tuberculosis rather than with malignant disease (for references, see Finlayson (1958)). Leaving aside various early records of actual expectorated fragments of carcinoma, the first mention of cancer cells in sputum is a remark in Walshe's A Practical Treatise on the Diseases of the Lungs (1860), in which he says that they have 'been occasionally found microscopically'. The first illustration is usually attributed to Beale (1861), though the primary was in the pharynx and the 'sputum' was obtained post mortem by Mr Newham (who had permission to examine only the throat but 'ventured as far as the chest'). A number of other early reports can be found, with illustrations, in the review by Grunze (1960). Systematic examination of sputum for the diagnosis of carcinoma of the lung was undertaken by Hampeln of Riga; his first case report appeared in 1887 and his final series in 1918-19, with 13 out of 25 cases correctly diagnosed by microscopy of the sputum.

It must be remembered that, in those days, carcinoma of the lung was quite uncommon. Indeed, it was possible to write a whole book about the microscopy of sputum in 1886 without mentioning cancer of the lung (Mackenzie, 1886).

Hampeln's work was not taken up systematically by others at the time, and the fact that malignant cells can be reliably identified in sputum had to be rediscovered by Leonard Dudgeon and his colleagues at St Thomas's Hospital, London.

Along with extensive studies on the cytology of scrapings from surgical specimens, of which a series of over 1000 were reported in 1934 (Dudgeon and Barrett, 1934), Dudgeon made a careful investigation of the possibility of identifying malignant cells in sputum, using smears wet-fixed with Schaudinn's solution and stained with haemalum and eosin. He had originally developed this method for studying the cytology of human milk (Dudgeon and Jewesbury, 1924). He did not rush into print and, by the time his one paper on the subject appeared (Dudgeon and Wrigley, 1935), he was already expert in making the diagnosis from sputum by this means. This series (which, unlike many much later studies, presented the data in tables) contained 38 cases of lung cancer. Of these, 26 were found to have malignant cells in the sputum, and there was one false positive. The rate of correct detection, $68 \%$, is about the same as that almost universally obtained today. Figure 4 shows one of Dudgeon and Wrigley's drawings illustrating oat-cells in sputum. It was accompanied by the first description of this distinctive cell type in smears. Dudgeon's method was in continuous use at St Thomas's from then onwards. ${ }^{1}$ Dudgeon's papers presented his data with a clarity and simplicity which has not always been imitated by his successors. He died in 1938 without having trained a sufficiently large nucleus of disciples in England to create a 'snowball' of pathologists able to apply his methods.

Wandall in Copenhagen pursued the subject, using a similar wet-fixation method, and in 1944 published a series of 100 cases of primary lung carcinoma, 84 of which were correctly diagnosed from the sputum, and in most of which it was possible to state the histological type. His published photomicrographs were good enough to be usefuf for teaching, unlike most of what had gone before.

Following the cytology explosion in America, resulting from the work of Papanicolaou, the cytological diagnosis of carcinoma of the lung from sputum and bronchial aspirates became a universally applied diagnostic test and, in practised hands, one of the most reliable.

\section{Miscellaneous applications of cytodiagnosis}

The examination of urine is as old as medicine, and the microscope added a new dimension to 'uroscopy'. In the various 19th century books on the subject of the urine, many drawings can be found showing different cell types encountered. In 1854, Beale, who for many years was the English protagonist of medical microscopy, illustrated cells from different parts of the urinary tract (Fig. 5). Malignant cells from carcinoma of the bladder were probably first described and illustrated by Lambl (1856) and soon $\mathrm{N}$ after by Neubauer and Vogel (1863), though $\mathscr{2}$ emphasis was placed on papillary fragments more 0 than on isolated cells. This application of cyto- $\bar{\varnothing}$ diagnosis was considered easy, but it was admitted ?

1 Some coloured photographs from Dudgeon's slides can be found in the historical note by Bamforth (1963). 


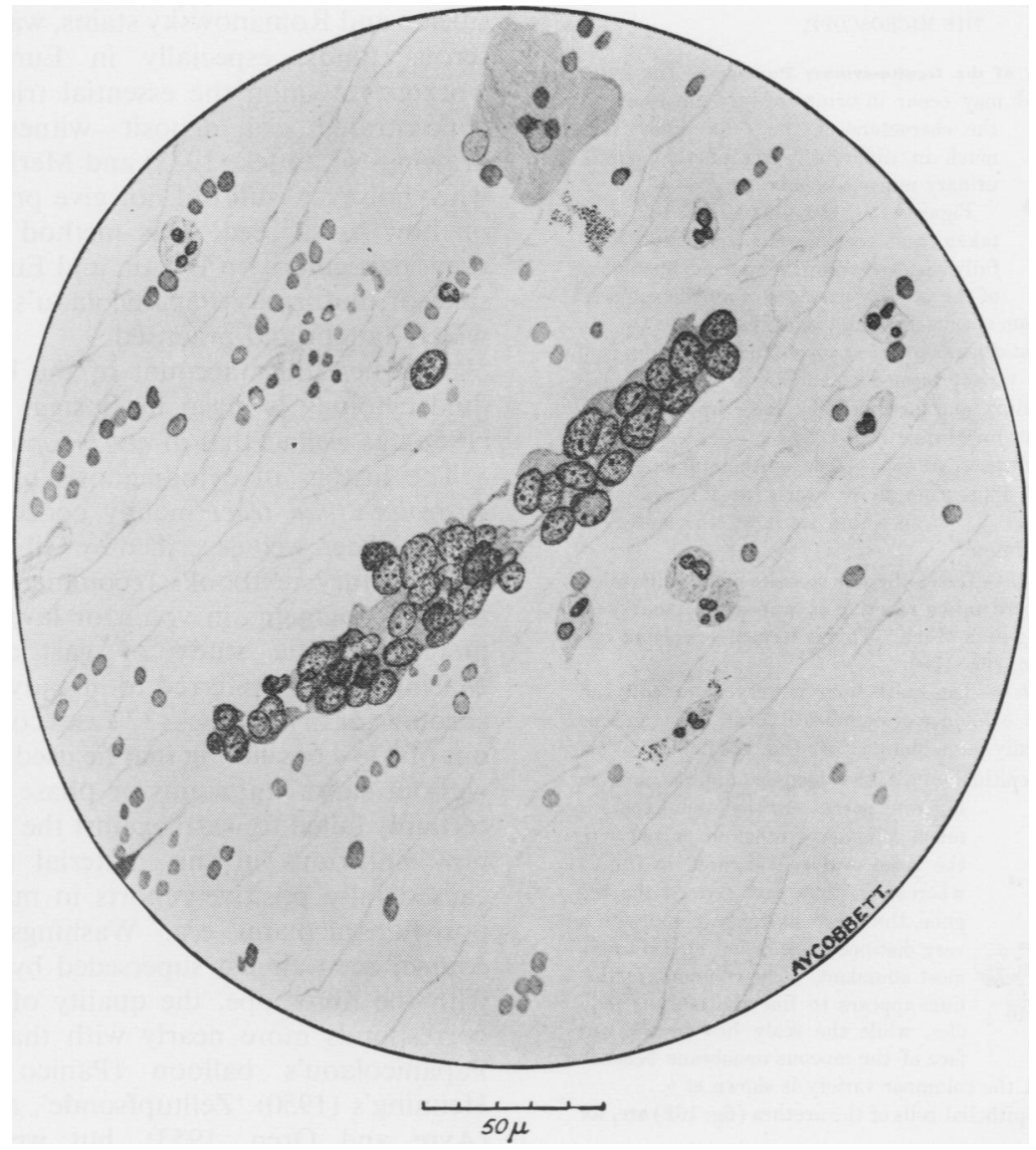

500. Fragment of growth in Sputum from Case 6r. Primary Carcinoma of Lung. Oat-celled type.

Fig. 4 One of the drawings from Dudgeon and Wrigley (1935), the first published illustration of oat-cells in sputum.

that cells from carcinoma of the kidney were much harder to find, as we still agree today. Beale (1878) illustrated cells resembling those of carcinoma found in the urine of a young girl with nephritis and put in some salutary words of caution; this was a most unusual thing to do in a period when any mention of doubts and mistakes was generally avoided in medical writing.

Apart from Quensel's (1918) observations using a new supravital staining technique, there were few advances in the cytology of urine until our own time, even though the microscopy of urine sediments has for long been 'routine'. Bamforth and Osborn (1958) described how the great pathologist James Ewing correctly identified malignant cells in his own urine, coming from a carcinoma of the bladder. This was just before the introduction of Papanicolaous' methods (Papanicolaou and Marshall, 1945). Even the next 30 years have not solved the formidable problem of exact cell identification in this particularly difficult material.

Serous fluids were the subject of numerous scattered observations in the 19th century from the late sixties onwards. Ehrlich's (1882) contribution has already been mentioned. Published drawings of the period tend to be non-informative, but an example of clearly recognisable adenocarcinoma cells can be seen in Spencer Wells's (1882) textbook on gynaecological tumours. Nobody had the idea of presenting the figures showing what proportion of malignant effusions could be correctly diagnosed by cytology, or how many such diagnoses were mistaken.

The first systematic study of the cells of effusions 


$$
\text { Zlit THE MICROSCOPE, }
$$

236. Eptihelium of the Genito-urtanry Pansages.-The forms 'if epithelium which may occur in urine are very numerous, ns Fig. 158. the characters of the cells differ very much in different parts of the genitourinary mucous membrane.

Figures 158, 159, 160, 161, $a, 162$, were taken from specimens of epithelium care. fully removed from the mucous membrane of the urinary passages of a male subject.

Figure 161 l, c, from specimens found in urine.

Kidury. - Cunwoluted portion of the tubes.-The epithelium is of Fig. 15y. the rariety termed glandular, or secreting epithelium, and forms a thick layer upon the basement membraue (fig. 158).

Straight portion. - The epithelium is flatter, 3 and approaches more nearly to the scaly rariety. It forms a thin layer on the surface of

Pelvis of the Kidney. - The epithelium consists of flat thin scales, which are united together at the edges without over-

Fig. 160. lapping each other. This is termed tesselated epi$<\equiv$ thelium (fig. 159).

Uieter.-The epithelium is very abundant, and

2 of the columnar or cylindrical form. The nucleus is usually large and distinct (fig. 160).

Bladder.-The epithelium of the bladder differs much in Fig. 161. different parts. In the fundus there is much columnar epithelium mixed with (5) $\rightarrow$ the large oval cells figured in 161 ; whereas, in that part termed the trigone, the large flattened cells, with a very distinct nucleus and nucleolus ar
most abundant. The columnar epithe

6ye lium appears to line the mucous folli-

cles, while the scaly lies on the sur face of the mucous membrane between

them. In fig. 161 the columnar variety is shown at $l$.

Ciethru.-The epithelial cells of the urethra (fig. 162) are, for

Fig. 5 A page from Beale's The Microscope and its Application to Clinical Medicine (1854). The separate identification of cells from different parts of the urinary tract, as found in the urine, is now thought to be very unreliable.

was carried out by Widal and Ravaut (1900) but their concern was to separate tuberculous pleurisy from other types, by differential counts of lymphocytes, polymorphs, and 'endothelial cells', and they practically ignored malignant effusions. In the early decades of this century it became common to search for malignant cells in sections of 'cell blocks' made from the centrifuged deposit, and this was the standard method in America until the introduction of Papanicolaou's wet-fixed smears. The work of Quensel (1928a, b) depended on supravital staining, and Fig. 6 shows an example of his photographs made from cells in suspension. Although his work was meticulously presented and was visibly superior to any results obtained with cell-blocks, very few workers troubled to continue with his method.

The haematological method, using air-dried smears and Romanowsky stains, was widely used for serous fluids, especially in Europe. Occasional workers hit upon the essential trick of using very concentrated cell deposit-witness the coloured drawings of Zadek (1933) and Merklen et al. (1933), who, however, still did not give proper instructions on how to succeed. This method is still routinely used, particularly in Britain and Europe, but for the sake of uniformity Papanicolaou's method is more widely taught and practised.

A rather fuller account of the history of serous fluid cytology is given by Spriggs and Boddington (1968), as well as that of cerebrospinal fluid.

The history of cytodiagnosis of tumours of the gastrointestinal tract mainly concerns the stomach and has been well described by Gibbs (1968). Several 19th century textbooks recommended a search for tumour fragments in vomit or lavage fluid, but the first systematic study of gastric washings was Marini's (1909), referred to already. It is difficult to account for his success-32 cases correctly diagnosed out of 37 -considering that he used wet preparations without supravital stains or phase contrast, and he certainly failed to warn against the pitfalls which are now notorious in this material and which have caused false positive reports in many series in the post-Papanicolaou era. Washings have now, of course, been almost superseded by brushings take with the fibrescope, the quality of which probabFy corresponds more nearly with that obtained from Papanicolaou's balloon (Panico et al., 1950), Henning's (1950) 'Zelltupfsonde', and Ayre's brush (Ayre and Oren, 1953), but we now have the additional precision of sampling a defined area.

After Papanicolaou, the field of gastrointestinal cytodiagnosis was studied particularly by the Chicago school, inaugurated by C. Rubin (for literature, see Prolla and Kirsner (1972)). In view of the bad prognosis of gastric carcinoma, this might be thought an ancillary method of no great importance, but Schade (1958) demonstrated that superficial lesions without invasion can be identified cytologically, and these are now being detected frequently, especially in Japan.

Blood cells have been studied microscopically ever since the 17th century, and the cytology of the $N$ haemopoietic organs is a subject on its own which $N$ cannot be covered here. The use of a needle to sample solid organs, even haemopoietic ones, was $\omega$ introduced by bacteriologists and parasitologists-? for instance, spleen puncture was used for typhoid and for kala-azar about the turn of the century, and $\Phi$ only in the 1930s for Hodgkin's disease and later for other blood disorders (Moeschlin, 1947). Marrow puncture was also first used by parasitologists, and later was introduced for haematological diagnosis by 


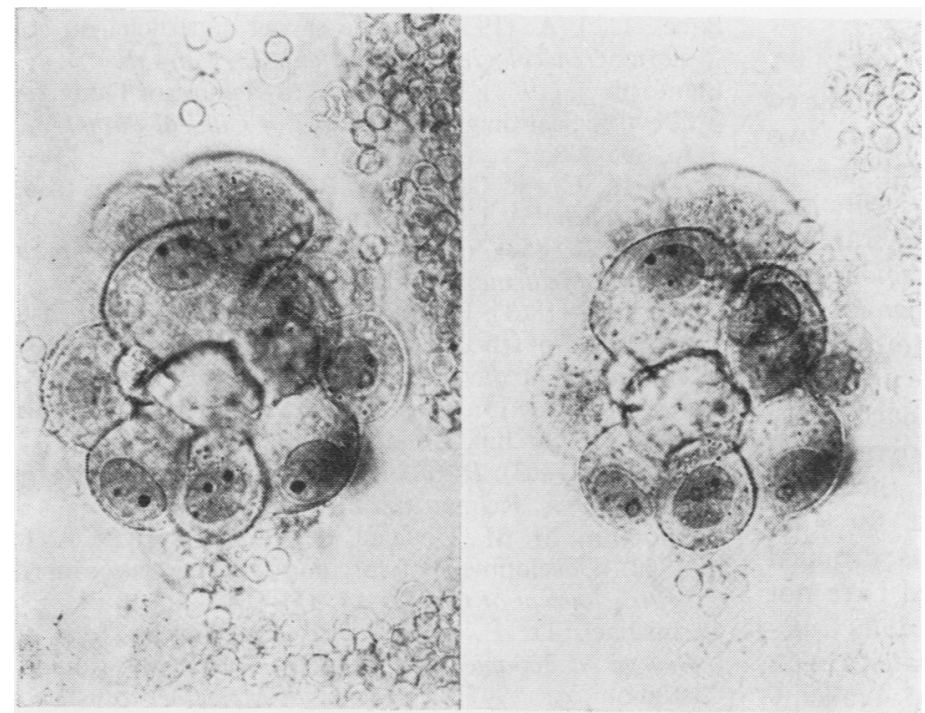

a

b

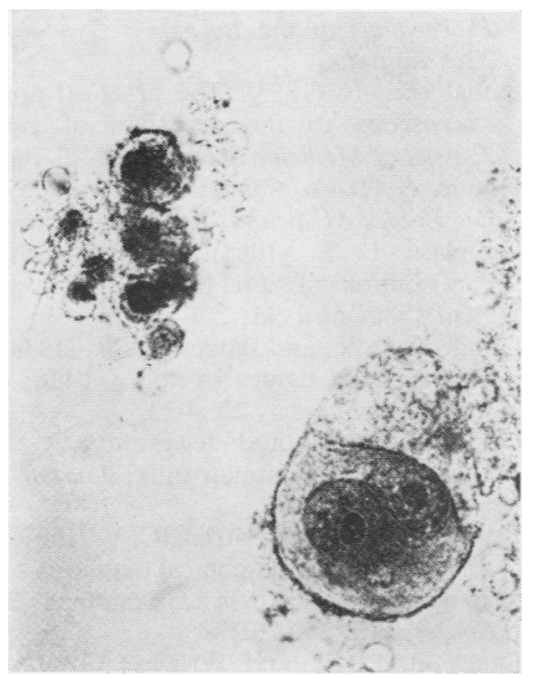

Fig. 68 .
Fig. 6 Photographs of ovarian carcinoma cells in pleural fluid, from Quensel (1928b). The cells are stained with methylene-blue-Cd + Sudan-Cd and examined in suspension.

Qucissel: Eirgïsse der Brust. und Banchhöhlen.

Arinkin (1929). Cytological study by lymph-node puncture has been in use rather longer (Guthrie, 1921). The main development of these methods was during and after the 1939-45 war.

Puncture cytology of the lung and liver has been used on a much smaller scale (for literature, see Lüdin (1955)), and fine-needle puncture of tumours, with diagnosis from smears rather than sections, has only recently and locally become popular, but its use is increasing, especially for the breast and prostate (Zajicek, 1974).

These methods are the logical development from earlier studies of smears made from open biopsies, such as those of Dudgeon (Dudgeon and Patrick, 1927; Dudgeon and Barrett, 1934). The most consistent use of the latter method has been made by the neurosurgeons, and in Britain this application has been routine for over 30 years (Russell et al., 1937). 
Note on the word 'cytology'

Librarians and booksellers are apt to be confused because the word 'cytology' has taken on two different meanings. The general study of cell biology has been called 'cytology' for at least 85 years and the word is still used in that sense; examples are the periodical International Review of Cytology, of Bourne and Danielli, and A History of Cytology by Arthur Hughes. Darlington's Recent Advances in Cytology (1st edition, 1932) had a more restricted subject, that of the chromosomes, particularly those of plants! With the widespread development of cytodiagnostic laboratories in hospitals, the name 'cytology' has been generally adopted for that specialty. (The adjective 'exfoliative' was dropped because in many cases the cells examined have not been exfoliated.) Accordingly, we have Acta Cytologica as the principal journal of the specialty, begun as the official journal of the International Academy of Gynaecological Cytology (1958), which has since changed its name to the International Academy of Cytology.

Now that the word has become ambiguous, the best that can be done is to qualify it or use another. The study of chromosomes has become 'cytogenetics', while the expression 'cell biology' has been adopted by the scientists who previously called themselves 'cytologists'. Medical cytodiagnosticians should speak of 'cytopathology', 'clinical cytology', 'diagnostic cytology', or 'cytodiagnosis'.

Books and articles on which I have drawn particularly heavily are Bamforth and Osborn (1958), Hughes (1959), Grunze (1960), and Carmichael (1973). I am indebted to the late Dr Lucia-Maria Babes for the information concerning her husband. I am also very grateful to Dr A. H. T. RobbSmith, the use of whose library was indispensable, and this article is dedicated to him on his retirement.

\section{References}

Arinkin, M. I. (1929). Die intravitale Untersuchungsmethodik des Knochenmarks. Folia Haematologica, 38, 233-240.

Ayre, J. E. (1947). Selective cytology smear for diagnosis of cancer. American Journal of Obstetrics and Gyneco$\log y, 53,609-617$.

Ayre, J. E. (1952). Cancer Cytology of the Uterus. Churchill, London.

Ayre, J. E., and Oren, B. G. (1953). A new rapid method for stomach-cancer diagnosis: the gastric brush. Cancer, 6, 1177-1181.

Babès, (sic), A. (1928). Diagnostic du cancer du col utérin par les frottis. Presse Médicale, 36, 451-454.
Babes, (sic), A. (1931). Sur le cancer superficiel du col utérin. Gynécologie et Obstétrique, 23, 417-433.

Bamforth, J. (1963). Pioneer work by Professor Dudgeon in cytological diagnosis. Journal of Clinical Pathology, 16, 395-398.

Bamforth, J., and Osborn, G. R. (1958). Diagnosis from cells. Journal of Clinical Pathology, 11, 473-482.

Beale, L. S. (1854). The Microscope and its Application to Clinical Medicine. Highley, London.

Beale, L. S. (1861). Examination of sputum from a case of cancer of the pharynx and the adjacent parts. Archives of Medicine (London), 2, 44-46.

Beale, L. S. (1878). The Microscope in Medicine, 4th edition. Churchill, London.

Billroth, T. (1863). Die allgemeine chirurgische Pathologie und Therapie. Reimer, Berlin.

Boddington, M. M., Cowdell, R. H., and Spriggs, A. I. (1960). Development of carcinoma of the cervix uteri. British Journal of Cancer, 14, 151-164.

Carmichael, D. E. (1973). The Pap Smear: Life of George N. Papanicolaou. Thomas, Springfield, Illinois.

Castiglioni, A. (1947). A History of Medicine, translated by E. B. Krumbhaar, 2nd edition. Knopf, New York.

Daniel, C., and Babeș, A. (1927). Posibilitatea diagnosticului cancerului uterin cu ajutorul frotiului. Proceedings of the Bucharest Gynaecological Society, 23rd January,

Donaldson, F. (1853). The practical application of the microscope to the diagnosis of cancer. American Journal of Medicine Sciences, 25, 43-70.

Donné, A. (1844). Cours de Microscopie Complémentaire des Etudes Médicales. Baillière, Paris.

Douglass, L. E. (1967). A further comment on the contributions of Aurel Babes to cytology and pathology. Acta Cytologica, 11, 217-224.

Dudgeon, L. S., and Barrett, N. R. (1934). The examination of fresh tissues by the wet-film method. British Journal of Surgery, 22, 4-22.

Dudgeon, L. S., and Jewesbury, R. C. (1924). The bacteriology of human milk. Journal of Hygiene, 23, 64-76.

Dudgeon, L. S., and Patrick, C. V. (1927). A new method for the rapid microscopical diagnosis of tumours: with an account of 200 cases so examined. British Journal of Surgery, 15, 250-261.

Dudgeon, L. S., and Wrigley, C. H. (1935). On the demonstration of particles of malignant growth in the sputum by means of the wet-film method. Journal of Laryngology and Otology, 50, 752-763.

Ehrlich, P. (1882). Beiträge zur Aetiologie und Histologie pleuritischer Exsudate. Charité-Annalen, 7, 199-230.

Finlayson, R. (1958). The vicissitudes of sputum cytology. Medical History, 2, 24-35.

Friedlaender, C. (1886). Microscopische Technik zum Gebranch bei medicinischen und pathologisch-anatomischen Untersuchungen, 3rd edition. Fischer, Berlin. Gates, O., and Warren, S. (1947). A Handbook for the Diagnosis of Cancer of the Uterus by the use of Vaginal Smears. 1st edition. Harvard University Press, Cambridge, Massachusetts.

Gibbs, D. D. (1968). Exfoliative Cytology of the Stomach. Butterworths, London. 
Gloyne, S. R. (1919). The clinical pathology of thoracic puncture fluids. Lancet, 1, 935-937.

Grunze, H. (1960). A critical review and evaluation of cytodiagnosis in chest diseases. Acta Cytologica, 4, 175-198.

Guthrie, C. G. (1921). Gland puncture as a diagnostic measure. Bulletin of the Johns Hopkins Hospital, 32, 266-269.

Hampeln, P. (1887). Über einen Fall von primärem Lungen-Pleura-Carcinom. St. Petersburger medizinische Wochenschrift, 12 (n.s. 4), 137-139.

Hampeln, P. (1918-19). Zur Symptomatologie und Diagnose der primären malignen Lungentumoren. Mitteilungen aus den Grenzgebeiten der Medizin und Chirurgie, 31, 672-718.

Henning, N. (1950). Die Cytodiagnostik maligner Tumoren. Folia haematologica (Leipzig), 70, 198-203.

Hughes, A. (1959). A History of Cytology. AbelardSchuman, London.

Lambl (1856). Über Harnblasenkrebs. Ein Beitrag zur mikroskopischen Diagnostik am Krankenbette. Vierteljahrschrift für die praktische Heilkunde (Prague), 49, 1-32.

Lebert, H. (1851). Traité Pratique des Maladies Cancéreuses. Baillière, Paris.

Lebert, H. (1857-61). Traité d'Anatomie Pathologique. Baillière, Paris.

Lüdin, H. (1955). Die Organpunktion in der klinischen Diagnostik. Karger, Basle.

Mackenzie, G. H. (1886). A Practical Treatise on the Sputum. Johnson, Edinburgh.

Marini, G. (1909). Über die Diagnose des Magenkarzinoms auf Grund der cytologischen Untersuchung des Spülwassers. Archiv für Verdauungskrankheiten, 15, 251-267.

Merklen, P., Waitz, R., and Kabaker, J. (1933). Sur la cytologie des épanchements pleuraux. Presse Médicale, 41, 1828-1831.

Moeschlin, S. (1947). Die Milzpunktion. Schwabe, Basle.

Müller, J. (1840). On the Nature and Structural Characteristics of Cancer and of those Morbid Growths which may be Confounded with it, translated by C. West. Sherwood, Gilbert and Piper, London.

Neubauer, C., and Vogel, J. (1863). A Guide to the Qualitative and Quantitative Analysis of the Urine, 4th edition, translated by W. O. Markham. New Sydenham Society, London.

Panico, F. G., Papanicolaou, G. N., and Cooper, W. A. (1950). Abrasive balloon for exfoliation of gastric cancer cells. Journal of the American Medical Association, 143, 1308-1311.

Papanicolaou, G. N. (1928). New cancer diagnosis. In Proceedings of the 3rd Race Betterment Conference, pp. 528-534. Race Betterment Foundation, Battle Creek, Michigan.

Papanicolaou, G. N. (1933). The sexual cycle in the human female as revealed by vaginal smear. American Journal of Anatomy, 52, 519-637.

Papanicolaou, G. N. (1954). Atlas of Exfoliative Cytology. Harvard University Press, Cambridge, Massachusetts.

Papanicolaou, G. N., and Marshall, V. F. (1945). Urine sediment smears as a diagnostic procedure in cancers of the urinary tract. Science, 101, 519-520.

Papanicolaou, G. N., and Traut, H. F. (1941). The diagnostic value of vaginal smears in carcinoma of the uterus. American Journal of Obstetrics and Gynecology, 42, 193-206.

Papanicolaou, G. N. and Traut, H. F. (1943). Diagnosis of Uterine Cancer by the Vaginal Smear. Commonwealth Fund, New York.

Pouchet, F. A. (1847). Théorie Positive de l'Ovulation Spontanée et de la fécondation des Mammifères et de l'espèce Humaine. Baillière, Paris.

Prolla, J. C., and Kirsner, J. B. (1972). Handbook and Atlas of Gastrointestinal Exfoliative Cytology. University of Chicago Press, Chicago.

Quensel, U. (1918). Untersuchungen über die Morphologie des Harnsediments bei Krankheiten der Nieren und der Harnwege und über die Entstehung der Harnzylinder. Nordiska Bokhandeln, Stockholm.

Quensel, U. (1928a). Zur Frage der Zytodiagnostik der Ergüsse seröser Höhlen. Acta Medica Scandinavica, 68, 427-457.

Quensel, U. (1928b). Zytologische Untersuchungen von Ergüssen der Brust- und Bauchhöhlen mit besonderer Berücksichtigung der karzinomatösen Exsudate. Acta Medica Scandinavica, 68, 458-501, and Supplement, 23.

Richardson, J. G. (1871). A Handbook of Medical Microscopy. Lippincott, Philadelphia.

Russell, D. S., Krayenbühl, H., and Cairns, H. (1937). The wet film technique in the histological diagnosis of intracranial tumours: a rapid method. Journal of Pathology and Bacteriology, 45, 501-505.

Schade, R. O. K. (1958). Exfoliative cytology of gastric carcinoma. British Medical Journal, 1, 743-744.

Spriggs, A. I. (1972). Population screening by the cervical smear. Nature, 238, 135-137.

Spriggs, A. I., and Boddington, M. M. (1968). The Cytology of Effusions in the Pleural, Pericardial and Peritoneal Cavities, and of Cerebrospinal Fluid, 2nd edition. Heinemann, London.

Stockard, C. R., and Papanicolaou, G. N. (1917). The existence of a typical oestrous cycle in the guinea pig; with a study of its histological and physiological changes. American Journal of Anatomy, 22, 225-283.

Tuckwell, W. (1907). Reminiscences of Oxford, 2nd edition. Smith, Elder \& Co., London.

Virchow, R. (1847). Zur Entwickelungsgeschichte des Krebses. Virchows Archiv für pathologische Anatomie, 1, 94-201.

Walshe, W. H. (1860). A Practical Treatise on the Diseases of the Lungs, 3rd edition. Walton, London.

Wandall, H. H. (1944). A study on neoplastic cells in sputum as a contribution to the diagnosis of primary lung cancer. Acta Chirurgica Scandinavica, 91, Supplement, 93.

Wells, T. S. (1882). On Ovarian and Uterine Tumours. Churchill, London.

Widal and Ravaut (1900). Applications cliniques de l'étude histologique des épanchements séro-fibrineux de la plèvre. Comptes Rendus des Séances de la Societé de Biologie, 52, 648-651, 651-653, and 653-655.

Zadek, I. (1933). Die Zytologie der Exsudate und Transsudate. In Handbuch der allgemeinen Hämatologie, 
edited by $\mathrm{H}$. Hirschfeld and A. Hittmair, Vol. 1, pt. 2, pp. 1373-1418. Urban and Schwarzenberg, Berlin.

Zajicek, J. (1974). Aspiration Biopsy Cytology. Part 1.
Cytology of Supradiaphragmatic Organs. Karger, Basle. Zinser, H. K. (1957). Die Zytodiagnostik in der Gynäkologie, 2nd edition. Fischer, Jena.

\section{The November 1977 Issue}

\section{THE NOVEMBER 1977 ISSUE CONTAINS THE FOLLOWING PAPERS}

Evaluation of the Hemalog D differential leucocyte counter J. W. CAIRNS, M. J. R. HEALY, D. M. STAFFORD, P. VITEK, AND D. A. W. WATERS

A comparative study for the enumeration of peripheral blood white cell counts below $2.0 \times 10^{9} / 1$ using counting chambers and the Coulter Counter Model 'S' K. E. HURD, M. K. PALMER, AND SHEILA HULL

Screening of blood donors for IgA deficiency: a study of the donor population of south-west England P. D. J. HOLT, N. P. TANDY, AND D. J. ANSTEE

Evaluation of a new test system for rubella haemagglutination inhibiting antibodies PAUL C. ROBERTS AND SANDRA J. HOBBS

Human papovavirus in Papanicolaou smears of urinary sediment detected by transmission electron microscopy D. V. COLEMAN, W. J. I. RUSSELL, J. HODGSON, TUN PE, AND J. F. MOWBRAY

Group B streptococci in women fitted with intrauterine devices R. G. MITCHELl, J. Guillebaud, AND D. G. DAY

Bacteriological findings in cultures of clinical material from Bartholin's abscess M. W. D. WREN

Light inactivation of metronidazole sensitivity discs P. H. JONES AND ANNE P. SCOTT

A comparison of three rapid methods for the detection of $\beta$-lactamase activity in Haemophilus influenzae A. SKINNER AND R. WISE

Endocarditis due to Cardiobacterium hominis R. S. JOBANPUTRA AND JEFFERY MOYSEY

Catecholamines and free fatty acids in myocardial infarction and angina SUBHASH C. SHARMA

Aminopyrine breath test in alcoholic liver disease and in patients on enzyme-inducing drugs $\mathrm{K}$. O. LEWIS, GEOFFREY NICHOLSON, P. LANCE, AND A. PATON
Prolyl hydroxylase in the skin of patients with obstructive jaundice THAN THAN, J. O'D. MCGEE, AND L. H. BLUMGART

Serum protein changes in breast cancer: a prospective study K. W. PETTINGale AND D. E. H. TEE

Multiple myeloma and oat cell carcinoma A. G. SMITH AND R. L. C. CUMMING

A new histochemical technique of use in the interpretation and diagnosis of adenocarcinoma and villous lesions in the large intestine C. F. A. CULLING, P. E. REID, ANN J. WORTH, AND W. L. DUNN

Histochemical comparison of the epithelial mucins in the ileum in Crohn's disease and in normal controlsC. F. A. CULLING, P. E. REID, W. L. DUNN, AND M. G CLAY

Technique for microdissection and measurement in biopsies of human small intestine ANNE FERGUSON, A. SUTHERLAND, T. T. MaCDONALD, AND FRANCES ALLAN

Report filing in histopathology W. K. BLENKINSOPP

Renal histopathological changes in a child with Laurence-Moon-Biedl syndrome BONITA FALKNER, CRAIG LANGMAN, AND SHELIA KATZ

\section{Technical methods}

A new anaerobic jar R. BURT AND K. D. PHILLIPS

A method for standardised resuspension of lymphocyte E-rosettes R. C. POTTS, P. C. HAYES, W. KAY, A. J. ROBERTSON, AND J. S. BECK

A simple body weighing machine D. SANDERS, T. SMOLENSKI, AND G. SLAVIN

Letter to the Editor

Book reviews

Copies are still available and may be obtained from the PUBLISHING MANAGER, BRITISH MEDICAL ASSOCIATION, TAVISTOCK SQUARE, LONDON WC8H 9JR, price $£ 3.00$, including postage 